\title{
ASAS LEX SPECIALIS SYSTEMATIS DAN HUKUM PIDANA PAJAK
}

\section{(Principle of Lex Specialist Systematic and Tax Criminal Law)}

\author{
Edward Omar Sharif Hiariej \\ Fakultas Hukum Universitas Gadjah Mada, Yogyakarta \\ Corresponding email: edward.omar@mail.ugm.ac.id
}

\section{Tulisan Diterima: 01-02-2021; Direvisi: 11-02-2021; Disetujui Diterbitkan: 11-02-2021 \\ DOI: http://dx.doi.org/10.30641/deiure.2021.V21.001-012}

\begin{abstract}
Principles of law have a unique character of being dynamic to reflect contemporary developments. Such character is also evident within the principle 'lex specilis derogat legi generali' that experience theoretical growth. This principle gives rise to 'lex specialis systematis'. There are two known sources in criminal law: general criminal law and special criminal law. One of the earliest examples of special criminal law is tax law which constitutes 'lex specialis systematis'. The research methodology in this article is a literature review as well as analyzing theories relevant to the principle 'lex specialis derogat legi generali'. This study indicates that the tax criminal law meets the criteria as lex specialis sistematis because the address is particular: taxpayers and tax officers. Besides, both the material provisions and the tax criminal law's formal provisions deviate from the KUHP and KUHAP. The suggestions that we can propose to the House of Representatives and the President as legislators are necessary to make fundamental changes to the law on general introductory provisions of taxation by remembering that the tax criminal law is ius singular as administrative law given criminal sanctions.
\end{abstract}

Keywords: lex specialis; criminal tax law

\begin{abstract}
ABSTRAK
Salah satu ciri asas hukum adalah bersifat dinamis sehingga dapat disesuaikan dengan perkembangan zaman. Demikian juga asas lex specialis derogat legi generali yang mengalami perkembangan secara teoretik. Salah satu derivate dari asas lex specialis derogat legi generali adalah asas lex specialis systematis. Dalam konteks hukum pidana, dikenal pembagian menurut sumber hukum pidana yang melahirkan hukum pidana umum dan hukum pidana khusus. Salah satu hukum pidana khusus tertua adalah hukum pidana pajak yang secara teoretik memenuhi kriteria sebagai lex specialis systematis. Metode penelitian dalam tulisan ini seluruhnya menggunakan studi pustaka. Selain menganalisis teori-teori yang aktual terkait asas lex specialis derogat legi generali dan hukum pidana pajak. Hasil Penelitian ini menunjukan bahwa hukum pidana pajak memenuhi kriteria sebagai lex specialis systematis karena adresat-nya sangat khusus yaitu wajib pajak dan petugas pajak. Selain itu, baik ketentuan materiil maupun ketentuan formil dalam hukum pidana pajak menyimpang dari KUHP dan KUHAP. Adapun saran yang dapat diusulkan kepada Dewan Perwakilan Rakyat dan Presiden sebagai pembentuk undang-undang adalah: Perlu melakukan perubahan mendasar terhadap undang-undang ketentuan umum pokok perpajakan dengan mengingat hukum pidana pajak adalah ius singular sebagai hukum adminstrasi yang diberi sanski pidana
\end{abstract}

Kata kunci: lex specialis; hukum pidana pajak 


\section{PENDAHULUAN}

Setiap mahasiswa fakultas hukum pada semester pertama pasti diajarkan tiga asas preferensi dalam dogmatik hukum. 1) Lex superior derogat legi inferior (aturan yang lebih tinggi mengesampingkan aturan yang lebih rendah). 2) Lex posteriori derogat legi priori (aturan yang baru mengesampingkan aturan terdahulu). 3) Lex specialis derogat legi generali (aturan khusus mengesampingan aturan umum). Bagi negaranegara yang mengikuti tradisi Eropa Kontinental termasuk Indonesia - pengaturan tindak pidana dilakukan dengan sistem kodifikasi yaitu memasukkan semua tindak pidana dalam KUHP kecuali terhadap tindak pidana militer dan tindak pidana pajak yang pengaturan di luar KUHP, asas lex specialis derogate legi generali sangtlah penting, terutama dalam aspek penegakkan hukum ${ }^{1}$.

Dalam doktrin, hukum pidana militer disebut sebagai ius speciale karena pengenaan hukum didasarkan pada offender dan bukan offences. Artinya, jika anggota militer kendatipun melakukan pelanggaran umum, tetap diadili dengan menggunakan hukum pidana militer. Demikian juga hukum pidana pajak yang dalam konteks doktrin dikenal dengan istilah ius singular karena memiliki sifat dan karakteristik yang lebih bernuansa ekonomis dalam rangka memperoleh pendapatan negara yang sebesar-besarnya. ${ }^{2}$

Pasca-Perang Dunia Kedua, pertumbuhan hukum pidana sangatlah masif sehingga berbagai kejahatan dan pelanggaran yang dikodifikasikan dalam KUHP tidak bisa menjerat berbagai kejahatan baru. Dalam konteks yang demikian bermunculanlah hukum pidana di luar kodifikasi yang disebut sebagai hukum pidana khusus. Pada hakikatnya hukum pidana khusus adalah lex specialis, namun tidak semua lex specialis adalah hukum pidana khusus. Perkembangan lebih lanjut di Indonesia terdapat kurang lebih 200 hukum pidana khusus yang tersebar dalam berbagai undang-undang sektoral. ${ }^{3}$

Keadaan yang demikian membawa dampak yang signifikan terhadap penegakkan hukum karena suatu perbuatan diatur oleh beberapa undang-undang. Jika pengaturan suatu perbuatan terdapat dalam hukum pidana umum (KUHP) dan hukum pidana khusus, persoalannya sederhana karena yang pasti digunakan adalah hukum pidana

\footnotetext{
1 Eddy O.S Hiariej, 2018, Lex Specialis Dalam Hukum Pidana, KOMPAS, 12 Juni 2018, hlm.7.
}

khusus. Hal ini secara ekplisit diatur dalam Pasal 63 ayat (2) KUHP yang menyatakan bahwa "Jika suatu perbuatan masuk dalam suatu aturan pidana yang umum, diatur pula dalam aturan pidana yang khusus, maka yang khusus itulah yang diterapkan". ${ }^{4}$ Akan tetapi jika suatu perbuatan diatur oleh lebih dari satu undang-undang yang bersifat hukum pidana khusus, maka persoalannya menjadi rumit, terlebih dalam hal penegakkan hukum karena akan terjadi tumpang tindih kewenangan dari berbagai aparat penegak hukum, terutama kewenagan Polri dan Penyidik Pegawai Negeri sipil (PPNS).

Problematika hukum dalam menghadapi pertumbuhan hukum pidana khusus di luar kodifikasi melahirkan perkembangan asas lex specialis derogat legi generali menjadi lex specialis systematis. Asas ini untuk menjawab bila terjadi konflik antara undang-undang yang satu dengan undang-undang yang lain yang keduakeduanya bersifat hukum pidana khusus. Sebagai misal, adalah hukum pidana pajak dengan tindak pidana korupsi yang diatur dalam Pasal 2 dan Pasal

3. Objek dari kedua undang-undang tersebut sama, yakni berkaitan dengan kerugian keuangan negara. Kendatipun hukum pidana pajak secara teoretik disebut ius singular, namun pada kenyataanya tindakan fiskus atau petugas pajak yang merugikan keuangan negara diadili dengan undang-undang tindak pidana korupsi sebagai contoh kasus Gayus Tambunan yang menerima putusan kasasi pada tahun 2012 dituntut oleh kejaksaan menggunakan UU Tipikor bukan dengan ketentuan hukum pidana pajak.

Berdasarkan uraian latar belakang di atas, adapun permasalahan dalam tulisan ini adalah: Apa kriteria dari lex specialis systematis?; dan Apakah hukum pidana pajak memenuhi kriteria sebagai lex specialis systematis dan bagaimana penegakkan hukumnya?

\section{METODE PENELITIAN}

Tulisan ini sepenuhnya berdasarkan studi pustaka terhadap berbagai bahan hukum. Adapun bahan hukum yang digunakan adalah bahan hukum primer berupa sejumlah undang-undang dan bahan hukum tertier seperti Kamus Besar Bahasa Indonesia (KBBI). Semua bahan hukum tersebut dianalisis dengan berbagai doktrin, teori, dan asas hukum secara konseptual.

\section{Ibid.}

Pasal 63 ayat (2) KUHP. 


\section{PEMBAHASAN DAN ANALISIS}

Analisis dan pembahasan meliputi dua hal utama yakni lex specialis systematis dan hukum pidana pajak.

\section{A. Kriteria Lex Specialis Systematis}

\section{a) Urgensi Asas Hukum}

Secara sederhana Bellefroid memberi arti asas hukum sebagai pengendapan hukum positif dalam suatu masyarakat. Dijelaskan lebih lanjut oleh Bellefroid bahwa asas hukum adalah norma dasar yang dijabarkan dari hukum positif dan oleh ilmu hukum dianggap berasal dari aturan-aturan yang lebih umum ${ }^{5}$. Oleh karena itu, asas hukum tidaklah dapat dipisahkan dari konteks kemasyarakatan di mana asas itu lahir. Paul Scholten tidak memberikan definisi asas hukum, namun menyatakan bahwa asas hukum adalah kecenderungan yang disyaratkan oleh pandangan kesusilaan pada hukum dan bersifat umum. Demikian pula van der Velden yang menyatakan bahwa asas hukum adalah tipe putusan tertentu yang dapat digunakan sebagai tolok ukur untuk menilai situasi atau digunakan sebagai pedoman berperi laku. Masih menurut Velden, asas hukum didasarkan atas satu nilai atau lebih yang menentukan situasi yang bernilai dan yang harus direalisasi ${ }^{6}$.

Pengertian asas hukum yang lebih detil dikemukakan oleh Sudikno Mertokusumo. Secara tegas dikatakan oleh Mertokusumo bahwa asas hukum bukanlah peraturan hukum konkrit tetapi pikiran dasar yang umum sifatnya atau latar belakang dari peraturan konkrit yang terdapat dalam dan di belakang setiap sistem hukum yang terjelma dalam peraturan perundang-undangan dan putusan hakim sebagai hukum positif dan dapat ditemukan dengan mencari sifat-sifat umum dalam peraturan konkrit tersebut. Demikian juga yang ditegaskan oleh van Eikema Hommes bahwa asas hukum tidak boleh dianggap sebagai norma hukum konkrit akan tetapi perlu dipandang sebagai dasardasar umum atau petunjuk-petunjuk bagi hukum yang berlaku? .

Ada beberapa karakteristik dari asas hukum. Pertama dari asas hukum adalah berlandaskan pada kenyataan masyarakat dan nilai-nilai yang dipilih sebagai pedoman untuk kehidupan bersama.

Kedua, karakteristik asas hukum ada yang dituangkan dalam peraturan hukum konkrit dan

5 Sudikno Mertokusumo, 2014, Penemuan Hukum : Suatu Pengantar, Cahaya Atma Pusataka, Yogyakarta, hlm. 5.

$6 \quad$ Ibid, hlm. 6. ada yang tidak dituangkan dalam peraturan hukum konkrit. Karakteristik ketiga dari asas hukum adalah ada asas hukum yang bersifat umum dan ada yang bersifat khusus. Lex specilais derogate legi generali adalah asas hukum yang bersifat umum. Artinya, semua bidang hukum yang ada berlaku asas tersebut.

Adapun cici-ciri asas hukum adalah sebagai berikut: Pertama, bersifat abstrak. Hal ini karena asas hukum pada umumnya merupakan latar belakang dari peraturan hukum konkrit atau apa yang terkandung dalam peraturan hukum konkrit. Ciri asas hukum yang kedua adalah bersifat umum. Artinya, asas hukum ini tidak hanya diterapkan pada suatu peristiwa konkrit. Kendatipun demikian, asas hukum mengenal pengecualian. Antara asas hukum yang satu dengan asas hukum yang lain terkadang ada pertentangan, akan tetapi antara asas hukum yang saling bertentangan, tidak dapat menegasikan antara satu dengan yang lain. Hal ini karena asas hukum tidak mengenal hirarki sebagai ciri ketiga.

Ciri keempat dari asas hukum adalah bersifat dinamis. Hal ini tidak terlepas dari adanya pertentangan antara asas hukum yang satu dengan asas hukum yang lain namun tidak dapat saling menegasikan sehingga asas hukum menjadi dinamis. Ciri dinamis dari asas hukum ini juga memberi makna bahwa asas hukum tidak terlepas dari konteks kemasyarakatan pada saat asas hukum itu lahir, namun dapat disesuaikan dengan perkembangan zaman. Ciri terakhir atau ciri kelima dari asas hukum adalah bahwa asas hukum hanyalah berupa anggapan atau suatu cita-cita. Nieuwenhuis menyatakan bahwa asas hukum itu memberi dimensi etis pada hukum ${ }^{8}$. Asas hukum adalah sesuatu yang idiil terjadi.

\section{b) Perkembangan Asas Lex Specialis derogate legi generalis}

Salah satu postulat dasar dalam ilmu hukum adalah lex specilais derogat legi generali yang secara harafiah berarti hukum khusus mengesampingkan hukum umum atau de speciale regel verdringt de algemene ${ }^{9}$. Dalam konteks hukum pidana, berbagai kejahatan dan pelanggaran yang tertuang dalam kitab undang-undang hukum pidana (KUHP) adalah hukum pidana umum, sedangkan berbagai kejahatan atau pelanggaran

\footnotetext{
Ibid, hlm. 7 .

Ibid., hlm. 8.

9 Ch.J., Enschede, 2002, Beginselen Van Strafrecht, Kluwer, Deventer, hlm. 186
} 
yang diatur dalam undang-undang tersendiri - di luar KUHP - adalah hukum pidana khusus. ${ }^{10}$

Bijzonder strafrecht atau hukum pidana khusus adalah hukum pidana yang menyimpang dari ketentuan-ketentuan umum hukum pidana baik dari segi materiil maupun formil. Artinya, ketentuan-ketentuan tersebut menyimpang dari ketentuan umum yang terdapat dalam KUHP maupun menyimpang dari ketentuan-ketentuan umum yang terdapat dalam Kitab Undang-Undang Hukum Acara Pidana (KUHAP).

Dewasa ini, di Indonesia banyak sekali undang-undang yang lahir kemudian, selain memuat ketentuan hukum pidana materiil yang menyimpang dari KUHP, juga memuat ketentuan beracara sendiri yang menyimpang dari KUHAP. Menurut penulis sekian banyak undang-undang tersebut adalah bijzonder delic atau tindak pidana khusus yang apabila dikenakan bersama-sama dengan ketentuan dalam KUHP, maka ketentuan tindak pidana khusus itulah yang harus digunakan berdasarkan postulat lex specialis derogat legi generali. Dengan demikian syarat lex specialis sebagai hukum pidana khusus adalah: Pertama, undang-undang yang berdiri sendiri dan ketentuan materiilnya menyimpang dari KUHP. Kedua, undang-undang yang berdiri sendiri dan ketentuan formil menyimpang dari KUHAP. Ketiga, undangundang yang berdiri sendiri namun ketentuan materiil dan formilnya menyimpang dari KUHP dan KUHAP. Ketiga syarat tersebut bersifat alternatif.

Perkembangan lebih lanjut, hukum pidana khusus masih dibagi menjadi dua yakni hukum pidana khusus yang merupakan undang-undang pidana dan hukum pidana khusus yang bukan merupakan undang-undang pidana. Hukum pidana khusus yang merupakan undang-undang pidana disebut juga sebagai hukum pidana khusus internal, sedangkan hukum pidana khusus yang bukan merupakan undang-undang pidana disebut sebagai hukum pidana khusus eksternal. Jumlah hukum pidana khusus internal jauh lebih sedikit bila dibandingkan dengan hukum pidana khusus eksternal. ${ }^{11}$

Ada perbedaan sifat dan karakter antara hukum pidana khusus internal dan hukum pidana khusus eksternal. Hukum pidana khusus internal bersifat primum rimedium. Artinya, hukum pidana

10 Sudarto, 2006, Kapita Selekta Hukum Pidana, Alumni, Bandung, hlm. 59-60.

11 Eddy O.S. Hiariej, loc.cit.

12 Jan Remmelink, 2003, Hukum Pidana : Komentar Atas Pasal-Pasal Terpenting Dari Kitab Undang- adalah sarana utama dalam penegakkan hukum. Selain itu karakter dari hukum pidana khusus internal sanksi pidana diformulasikan secara kumulatif antara pidana penjara dan denda. Sanksi pidana tidaklah bersifat subtitusi. Hal ini berbeda dengan hukum pidana khusus eksternal yang bersifat pidana ultimum rimedium. Artinya, hukum pidana adalah sarana akhir dalam penegakkan hukum jika sarana penegakkan hukum lainnya tidak lagi berfungsi. ${ }^{12}$ Hukum pidana khusus eksternal pada hakikatnya adalah hukum administrasi yang diberi sanski pidana. Oleh karena itu, sanksi administrasi adalah subtitusi dari sanksi pidana sebagaimana prinsip una via. Artinya, jika suatu perkara telah diselesaikan secara administrasi maka tertutuplah peluang penyelesaiakan perkara tersebut dengan sarana hukum lainnya.

Problematika lebih lanjut, terkadang suatu perbuatan diatur lebih dari satu undang-undang yang dikualifikasikan sebagai hukum pidana khusus. Sebagai misal, ketentuan tentang larangan merugikan keuangan negara atau perekonomian negara. Substansi larangan ini diatur paling dalam tiga undang-undang sebagai hukum pidana khusus; masing-masing adalah undang-undang pemberantasan tindak pidana korupsi, undangundang ketentuan umum pokok perpajakan dan undang-undang perbankan. Jika terjadi permasalahan kerugian keuangan negara, undangundang manakah yang digunakan? Tindak pidana pajak, tindak pidana perbankan dan tindak pidana korupsi merupakan lex specialis dari KUHP.

Jawaban atas pertanyaan tersebut tentunya akan mempengaruhi penegakan hukum pidana karena hukum formil yang diatur oleh ketiga undang-undang tersebut berbeda. Jika menggunakan undang-undang ketentuan umum perpajakan, maka penegakan hukumnya dilakukan oleh penyidik pajak. Jika menggunakan undangundang perbankan, maka penegakkan hukumnya dilakukan oleh Polri. Bila menggunakan undangundang pemberantasan tindak pidana korupsi, maka penegakannya dapat dilakukan oleh polisi, jaksa maupun Komisi Pemberantasan Korupsi (KPK).

Dalam perkembangan ilmu hukum termasuk hukum pidana - asas lex specialis derogat legi generali tidak bisa menyelesaikan

Undang Hukum Pidana Belanda Dan Padanannya Dalam Kitab Undang-Undang Hukum Pidana Indonesia, Penerbit PT Gramedia Pustaka Utama, Jakarta, hlm. 7 
sengketa yuridis bilamana terjadi suatu perbuatan yang diancam lebih dari satu undang-undang yang dikualifikasikan sebagai bijzonder delic atau delik khusus atau tindak pidana khusus atau hukum pidan akhusus. Jika demikian halnya, maka yang digunakan adalah lex spesialis systematis sebagai derivat atau turunan dari asas lex specialis derogat legi generalis. Menurut Remmelink, asas ini di Belanda dikenal dengan istilah specialitas yuridikal atau specialitas sistematikal ${ }^{13}$. Sementara

Enschede menyebutnya sebagai logische specialiteit ${ }^{14}$.

Dalam konteks hukum pidana, ada tiga ukuran yang menjadi parameter suatu undangundang dikualifikasikan sebagai lex specialis sistematis. Pertama, ketentuan pidana materiil dalam undang-undang tersebut menyimpang dari ketentuan umum yang ada. Kedua , undang-undang tersebut mengatur hukum pidana formil yang juga menyimpang dari ketentuan acara pidana pada umumnya. Ketiga, adresat atau subjek hukum dalam undang-undang tersebut bersifat khusus. ${ }^{15}$

Apabila kita menganalisis undang-undang ketentuan umum perpajakan yang mencakup tindak pidana pajak, undang-undang perbankan, dan undang-undang pemberantasan tindak pidana korupsi berdasarkan ketiga parameter yang menjadi ukuran lex specialis sistematis, mana dari ketiga undang-undang tersebut yang memenuhi kualifikasi sebagai lex specialis sistematis Ketentuan materiil hukum pidana pajak menyimpang dari KUHP. Demikian pula ketentuan formil dalam hukum pidana pajak yang menyimpang dari KUHAP. Selain itu adresat dari hukum pidana pajak bersifat khusus yakni wajib pajak dan fiscus atau petugas pajak.

Tindak pidana perbankan sebagaimana yang diatur dalam undang-undang perbankan maupun undang-undang Bank Indonesia, baik hukum materiil maupun hukum formil menyimpang dari KUHP dan KUHAP, hanya saja adresat dalam tindak pidana perbankan bersifat umum. Hal yang sama juga terdapat dalam undang-undang pemberantasan tindak pidana korupsi. Kendatipun ketentuan materiil dan formilnya menyimpang dari KUHP dan KUHAP, namun menurut penulis adresat dalam undang-undang pemberantasan tindak pidana korupsi bersifat umum, khususnya Pasal 2 dan Pasal 3 undang-undang a quo yang

\footnotetext{
Ibid., hlm. 578

Ch. J., Enschede, Op.Cit., hlm. 186.

Eddy O.S. Hiariej, loc.cit.

Eddy O.S. Hiariej, loc.cit.
}

menyangkut kerugian keuangan negara atau perekonomian negara.

Dengan demikian berdasarkan kriteria lex specialis systematis, hanya hukum pidana pajaklah yang memenuhi kriteria tersebut, sedangkan tindak pidana perbankan dan tindak pidana korupsi tidak memenuhi kriteria sebagai lex specialis systematis. Terlebih, Pasal 14 undang-undang tindak pidana korupsi telah membatasi diri bahwa hanya perbuatan dalam undang-undang tersebut dan atau undang-undang lainnya yang secara tegas menyatakan sebagai tindak pidan korupsi yang akan diproses seuai dengan undang-undang a quo.

Perkembangan lebih lanjut dari asas lex specialis systematis adalah jika dua atau lebih hukum pidana khusus mengatur hal yang sama dan tidak bisa diselesiakan atau dengan kata lain menimbulkan problematika dalam penegakkan hukum, maka lahirlah asas lex consumen derogate legi consumte yang berarti hukum pidana khusus yang satu mengabsorbsi hukum pidana khusus lainnya. Dasar pemberlakuan lex consumen derogate legi consumte adalah berdasarkan fakta yang dominan dalam suatu perkara. ${ }^{16}$

\section{B. Hukum Pidana Pajak dan Asas Lex Specialis Systematis}

\section{a) Pembagian Hukum Pidana}

Paling tidak ada lima pembagian hukum pidana, masing-masing adalah hukum pidana materiil - hukum pidana formil; hukum pidana objektif - hukum pidana subjektif; hukum pidana berdasarkan adresat; hukum pidana umum hukum pidana khusus; dan hukum pidana nasional - hukum pidana lokal serta hukum pidana internasional. Hukum pidana materiil pada dasarnya berisi ketentuan umum perihal keberlakuan suatu aturan hukum pidana dan juga perbuatan-perbuatan yang dikualifikasikan sebagai tindak pidana. Sedangkan hukum pidana formil adalah untuk menegakkan hukum pidana materiil ${ }^{17}$.

Wayne R. Lafave tidak menggunakan istilah hukum pidana materiil dan hukum pidana formil melainkan menggunakan istilah hukum pidana substantif dan hukum pidana prosedural. Kendatipun tidak memberi definisi, namun Lafave menyatakan bahwa hukum pidana substantif memberi perhatian terhadap tindakan, mental state keadaan dan konsekuensi beserta berbagai macam

17 Eddy O.S Hiariej, 2016, Prinsip-Prinsip Hukum Pidana, Cahaya Pustaka Atma, Yogyakarta, hlm. 22. 
kejahatan, sedangkan hukum pidana prosedural berawal dari penyidikan sampai pelaksanaan putusan $^{18}$. Adapula yang menyebut hukum pidana materiil sebagai hukum pidana in abstracto dan hukum pidana formil sebagai hukum pidana in concreto $^{19}$.

Pembagian hukum pidana yang lain adalah hukum pidana objektif yang juga disebut sebagai jus poenale dan hukum pidana subjektif yang dikenal dengan istilah jus puniendi. Vos mengaartikan hukum pidana onjektif atau jus poenale sebagai aturan-aturan hukum objektif meliputi hukum pidana materiil yang mengatur keadaan yang timbul dan tidak sesuai dengan hukum serta hukum acara beserta sanksi (hukum penintentir) aturan mengenai kapan, siapa dan bagaimana pidana dijatuhkan, sedangkan pengertian hukum pidana subjektif atau jus puniendi dikatakan sebagai hak subjektif penguasa terhadap pemidanaan, terdiri dari hak untuk menuntut pidana, menjatuhkan pidana dan melaksanakan pidana ${ }^{20}$.

Selanjutnya adalah hukum pidana berdasarkan adresat. Adresat adalah subjek hukum yang ditujukan oleh suatu peraturan perundangundangan. Pada dasarnya adresat hukum pidana berlaku untuk setiap orang dalam kapasitasnya sebagai individu. Akan tetapi dalam perkembangannya ada adresat hukum pidana yang ditujukan kepada orang-orang tertentu. Mereka yang memiliki profesi sebagai seorang militer, jika melakukan pelanggaran hukum pidana, diadili berdasarkan Kitab Undang-Undang Hukum Pidana Militer (KUHPM). Pengadilan yang mengadili pun adalah Pengadilan Militer ${ }^{21}$.

Pembagian hukum pidana yang lain adalah hukum pidana umum dan hukum pidana khusus. Hukum pidana umum adalah hukum pidana yang ditujukan dan berlaku bagi setiap orang sebagai subjek hukum tanpa membeda-bedakan kualitas pribadi subjek hukum tertentu. Dapat pula dikatakan bahwa hukum pidana umum adalah hukum pidana dalam kodifikasi. Jika dihubungkan dengan hukum pidana materiil dan hukum pidana formil, maka materiil hukum pidana umum dikodifikasikan dalam KUHP dan formil hukum pidana umum dikodifikasikan dalam KUHAP ${ }^{22}$.

18 Wayne R. Lafave, 2010, Principle Of Criminal Law, West A Thomson Reuters Business, hlm. 2.

19 Satochid Kartanegara (tanpa tahun), Hukum Pidana, Balai Lektur Mahasiswa, hlm. 2

20 H.B Vos, 1950, Leerbook Van Nederlands Strafrecht, Derede Herziene Druk, H,D., Tjeenk Willink \& Zoon N.V. - Harlem, hlm. 1.

21 Eddy O.S Hiariej, Op.Cit., hlm. 23.
Pembagian hukum pidana yang terakhir adalah berdasarkan wilayah berlakunya hukum pidana. Pada dasarnya ada kesatuan hukum pidana nasional yang berlaku di seluruh wilayah Indonesia yang disebut sebagai unifikasi hukum pidana. Hukum pidana nasional ini baik meliputi hukum pidana materiil maupun hukum pidana formil, baik hukum pidana umum maupun hukum pidana khusus. Dasar keberlakuan hukum pidana nasional adalah asas teritorial yang berarti bahwa ketentuan pidana berlaku bagi setiap orang yang melakukan tindak pidana di seluruh wilayah Indonesia.

Selain hukum pidana nasional, ada juga hukum pidana lokal yang dibuat oleh Dewan Perwakilan Rakyat Daerah bersama-sama dengan Gubernur, Bupati atau Walikota. Bentuk hukum pidana lokal dimuat dalam Peraturan Daerah dan hanya berlaku bagi daerah tersebut saja. Selain hukum pidana nasional dan hukum pidana lokal, ada juga hukum pidana internasional yang keberlakuannya bersifat universal. Hukum pidana internasional ini bertolak dari perkembangan zaman bahwa terdapat perbuatan-perbuatan yang dilarang yang kekuatan berlakunya tidak hanya dipertahankan oleh kedaulatan suatu negara tetapi juga dipertahankan oleh masyarakat internasional. Perbuatan-perbuatan tersebut kemudian dikualifikasikan sebagai kejahatan terhadap masyarakat internasional atau delicta jure gentium.

Kejahatan-kejahatan internasional merupakan substansi dari hukum pidana internasional.

\section{b) Hukum Pidana Pajak dan kaitannya} dengan Hukum Pidana Khusus lainnya

Hukum Pidana Pajak masuk ke dalam Tindak Pidana Ekonomi. Tindak Pidana Ekonomi ataupun Tindak Pidana di Bidang Ekonomi, tidak memiliki definisi yang tegas dan jelas, baik di tingkat Nasional maupun Internasional. ${ }^{23}$ Pada level internasional terdapat berbagai usulan megenai terminologi yang dipakai, hal ini bisa berkaitan dengan white-collar crimes, commercial crimes, business crimes, corporate crimes, economic crimes, dan berbagai bentuk terminologi yang digunakan. ${ }^{24}$ Bahkan, terdapat juga terminologi yang dianggap sebagai induk kejahatan terhadap ekonomi, yakni Financial Abuse dimana di dalamnya terdapat Financial

22 Ibid, hlm. 24

23 Bengt Larsson, "What is 'economic' about 'economic crime'?", Chapter Buku, White-Collar Crime Research. Old Views and Future Potentials, The national council for crime prevention, Sweden, hlm. 123.

24 Ibid. 
Crime. Sekalipun dikatakan bahwa terminologi financial abuse tidak begitu tegas dan cukup luas. ${ }^{25}$

Financial Abuse atau penyelahagunaan di bidang finansial merupakan definisi yang luas dimana melingkupi tidak hanya aktivitas ilegal yag memiliki dampak terhadap sistem finansial, namun juga aktivitas lain yang berkaitan dengan pajak dan peraturan perekonomian lainnya. ${ }^{26}$

Dalam doktrin hukum pidana, hukum pidana pajak disebut sebagai ius singulare karena memiliki sistem norma dan sanksi tersendiri. Bersama-sama dengan hukum pidana militer yang disebut sebagai ius specilae, hukum pidana pajak merupakan hukum pidana khusus tertua di dunia ${ }^{27}$. Jika diukur berdasarkan ketiga parameter lex specialis sistematis di atas, tindak pidana pajak yang diatur dalam undang-undang ketentuan umum perpajakan memenuhi kualifikasi sebagai lex specialis systematis.

Argumentasinya, ketentuan materiil terkait tindak pidana pajak dalam undang-undang ketentuan umum perpajakan bersifat khusus. Demikian pula ketentuan formil mengatur hal yang menyimpang dari ketentuan hukum acara yang diatur oleh KUHAP. Sedangkan adresat atau subjek hukum yang dapat dijerat dengan tindak pidana pajak bersifat khusus pula yakni wajib pajak dan petugas pajak. Selain itu, karakter hukum pidana pajak amat sangat khusus. Di samping memiliki norma dan sanksi hukum yang mengandung sifat administratif dan pidana, hukum pidana pajak juga didasarkan pada asas-asas yang bersifat ekonomis dan finansial.

Bila dilihat dari pembagian hukum pidana khusus menjadi hukum pidana khusus internal dan hukum pidana khusus eksternal, maka hukum pidana pajak adalah hukum pidana khusus eksternal. Artinya, hukum pidana pajak pada hakikatnya adalah hukum administrasi yang diberi sanksi pidana di dalamnya. Pertanyaan lebih lanjut, apakah hukum pidana pajak saat ini mengandung sifat dan karakter dari hukum pidana khusus eksternal sebagaimana yang telah diutarakan di atas ? Untuk menjawab pertanyaan tersebut, perlu dikaji dua ketentuan dalam undang-undang ketentuan umum pokok perpajakan.

Pertama, Pasal 13A undang-undang ketentuan umum perpajakan. Sebagian ahli, penulis berpendapat bahwa sistem hukum pidana pajak masih berdasarkan prinsip ultimum

25 International Monetary Fund, "Financial System Abuse, Financial Crime and Money Laundering", Background Paper, February 12, 2001, hlm. 3.

26 Ibid. remedium. Secara tegas Pasal 13A undang-undang a quo menyatakan, "Wajib pajak yang karena kealpaannya tidak menyampaikan Surat Pemberitahuan atau menyampaikan Surat Pemberitahuan, tetapi isinya tidak benar atau tidak lengkap atau melampirkan keterangan yang isinya tidak benar sehingga dapat menimbulkan kerugian pada pendapatan negara, tidak dikenai sanksi pidana apabila kealpaan tersebut pertama kali dilakukan oleh wajib pajak dan wajib pajak tersebut melunasi kekuarangan pembayaran jumlah pajak yang terutang beserta sanksi administrasi berupa kenaikan sebesar 200\% (dua ratus persen) dari jumlah pajak yang kurang dibayar yang ditetapkan melalui penerbitan Surat Ketetapan Pajak Kurang Bayar".

Penjelasan pasal a quo menyebutkan, "Pengenaan sanksi pidana merupakan upaya terakhir untuk meningkatkan kepatuhan wajib pajak. Namun, wajib pajak yang melanggar pertama kali ketentuan sebagaimana dimaksud dalam Pasal 38 tidak dikenai sanksi pidana, tetapi dikenai sanksi administrasi. Oleh karena itu, wajib pajak yang karena kealpaannya tidak menyampaikan Surat Pemebritahuan atau menyampaikan Surat Pemberitahuan, tetapi isinya tidak benar atau tidak lengkap atau melampirkan keterangan yang isinya tidak benar sehingga dapat menimbulkan kerugian pada pendapatan negara tidak dikenai sanksi pidana apabila kealpaan tersebut pertama kali dilakukan wajib pajak. Dalam hal ini, wajib pajak tersebut wajib melunasi kekuarangan pembayaran jumlah pajak yang terutang beserta sanksi administrasi berupa kenaikan sebesar 200\% (dua ratus persen) dari jumlah pajak yang kurang bayar".

$\underline{\text { Kedua }}$, Pasal 44 B ayat (1) undang-undang $a$ quo menegaskan, "Untuk kepentingan penerimaan negara, atas permintaan Menteri Keuangan, Jaksa Agung dapat menghentikan penyidikan tindak pidana di bidang perpajakan paling lama dalam jangka waktu 6 (enam) bulan sejak tanggal surat permintaan". Penjelasannya, "Untuk kepentingan penerimaan negara, atas permintaan Menteri Keuangan, Jaksa Agung dapat menghentikan penyidikan tindak pidana perpajakan sepanjang perkara pidana tersebut belum dilimpahkan ke pengadilan".

Pasal 44 B ayat (2) menyebutkan, "Penghentian penyidikan tindak pidana di bidang

27 Bambang Poernomo, 1984, Pertumbuhan Hukum Penyimpangan Di Luar Kodifikasi Hukum Pidana, Bina Aksara, Jakarta, hlm. 19. 
perpajakan sebagaimana dimaksud pada ayat (1) hanya dilakukan setelah wajib pajak melunasi utang pajak yang tidak atau kurang dibayar atau yang tidak seharusnya dikembalikan dan ditambah dengan sanksi administrasi berupa denda sebesar 4 (empat) kali jumlah pajak yang tidak atau kurang dibayar, atau yang tidak seharusnya dikembalikan".

Berdasarkan kedua pasal tersebut ada beberapa argumentasi bahwa pasal-pasal dimaksud menyatakan sanksi pidana dapat ditiadakan sepanjang wajib pajak bersedia membayar denda. Artinya, penegakan hukum pidana bersifat ultimum remedium yang baru dapat diterapkan setelah masalah administrasi tidak dapat diselesaikan atau dengan kata lain langkah penyelesaian tindakan pidana melalui peradilan pidana adalah ultimum remedium. ${ }^{28}$

Ada juga yang berpendapat bahwa dalam kaitannya dengan undang-undang ketentuan umum perpajakan maka ultimum remedium adalah last effort yaitu langkah terakhir pembayaran pajak yang akan dimasukan ke kas negara apabila upayaupaya yang tersebut dalam ketentuan perpajakan tidak terpenuhi sehingga bilamana ada indikasi tindak pidana dan ditindaklanjuti dengan proses pidana. Sanksi pidana pajak merupakan upaya terakhir (ultimum remedium) dalam penegakan hukum pajak artinya bahwa tindakan administrasi didahulukan atau dituntaskan daripada membawa masalah pajak ke penyidikan sebab undang-undang a quo misinya untuk mengamankan penerimaan negara sehingga dapat mengisi kas negara.

Pendapat lain menyatakan bahwa pengenaan sanksi pidana dalam undang-undang a quo, termasuk dalam pidana administratif bukan dalam kategori kejahatan sehingga ketentuan pidana dalam undang-undang tersebut tidak perlu berupa rumusan delik tetapi rumusan perbuatan administratif. Pasal 38 dan 39 undang-undang $a$ quo harus dipahami dalam hubungan sistematis kontsruktual dengan Pasal 13A. Dengan demikian, pengenaan sanksi pidana tanpa didahului dengan Pasal 13A adalah prematur sehingga berakibat batal demi hukum karena cacat secara prosedur. Jadi dalam hal ada dakwaan berdasarkan Pasal 38 dan Pasal 39 undang-undang a quo seyogyanya eksepsi diterima, surat dakwaan batal demi hukum dan terdakwa dibebaskan.

\footnotetext{
${ }^{28}$ Jan Remmelink, Op.cit., hlm 7

${ }^{29}$ Yoserwan, 2020, Fungsi Sekunder Hukum Pidana

Dalam Penanggulangan Tindak Pidana Perpajakan,
}

Melihat pada penelitian terlebih dahulu yang mengatakan bahwa pelaksaan fungsi sekunder hukum pidana dapat dilaksanakan dalam tahapan penyidikan dan penuntutan dan mekanisme penghentian dan penuntutan dengan lebih menyelesaikan secara administratif dan sanksi administratif, dalam tahapan pengadilan fungsi sekunder juga bisa dilaksanakan dengan lebih mengedepankan pemberian sanksi pidana denda, sehingga dapat mengoptimalkan pemasukan bagi keuangan negara dengan membayar kembali kerugian negara oleh wajib pajak sekalis merealisasikan fungsi budgeter dari pajak. ${ }^{29}$

Argumentasi yang lain menyatakan normanorma administratif merupakan wacthdog yaitu alat pemaksa berupa ketentuan pidana supaya norma-norma administratif tersebut ditaati. Hal ini menandakan bahwa mekanisme adminsitratif harus didahulukan sebagai suatu upaya penyelesaian suatu persoalan sebelum menggunakan mekanisme pidana.

Berdasarkan pendapat-pendapat tersebut di atas, argumentasi penulis adalah sebagai berikut: Pertama, dalam doktrin hukum pidana, sebagaimana telah diutarakan pada awal tulisan ini bahwa hukum pidana pajak disebut sebagai ius singulare karena memiliki sistem norma dan sanksi tersendiri. ${ }^{30}$ Hukum pidana pajak merupakan hukum pidana khusus tertua di dunia yang memiliki karakter amat sangat khusus. Di samping memiliki norma dan sanksi hukum yang mengandung sifat administratif dan pidana, hukum pidana pajak juga didasarkan pada asas-asas yang bersifat ekonomis dan finansial.

Kedua, dalam perkembangan ilmu hukum, hukum pidana pajak dikualifikasikan sebagai lex spesialis systematis sebagai derivat atau turunan dari asas lex specialis derogat legi generalis. Berdasarkan ukuran ${ }^{31}$ 1) Ketentuan pidana materiil dalam undang-undang tersebut menyimpang dari ketentuan umum yang ada; 2) Undang-Undang tersebut mengatur hukum pidana formil yang juga menyimpang dari ketentuan acara pidana pada umumnya; 3) Adresat atau subjek hukum dalam undang-undang tersebut bersifat khusus, yakni wajib pajak dan petugas pajak.

Ketiga, adanya sanksi administrasi dan sanksi pidana dalam tindak pidana pajak, pada awalnya menempatkan sanksi pidana sebagai ultimum remedium. Artinya, hukum pidana

Jurnal Penelitian Hukum DE JURE, Vol 20. No.2 (Juni 2020), hlm 175.

30 Bambang Poernomo, Loc.cit.

31 Eddy OS Hiariej, 2014, Op.cit., hlm 27. 
digunakan jika sarana penegakan hukum lainnya tidak lagi berfungsi dan ini disesuaikan dengan sifat dan karakter hukum pidana pajak sebagaimana yang disebutkan di atas. Akan tetapi dalam perkembangannya, sanksi pidana dalam hukum pidana pajak tidak lagi bersifat ultimum remedium melainkan bersifat premium remedium hal ini berdasar pada: 1) Perkembangan teori yang menyatakan bahwa tidak pidana di sektor perpajakan merupakan bagian dari tindak pidana ekonomi ${ }^{32}$; 2) Tindak pidana ekonomi sangat merugikan keuangan dan perekonomian negara; 3 ) tindak pidana ekonomi sering kali dilakukan secara terorganisasi dengan modus operandi yang sulit sehingga tidak mudah untuk membuktikannya.

Keempat, dengan menggunakan metode perbandingan, tindak pidana pajak di Belanda telah dikualifikasikan sebagai Economic Delicten atau delik-delik ekonomi. Artinya, bersama-sama dengan tindak pidana ekonomi lainnya seperti tindak pidana perbankan, tindak pidana pencucian uang dan korupsi, tindak pidana pajak merupakan bijzondere delic yang bersifat premum remidium sehingga penegakan sanksi administrasi bukan lagi merupakan substitusi dari sanksi pidana dalam konteks tindak pidana pajak.

Kelima, ketentuan pasal 13A dan Pasal 39 (1) huruf c Undang-undang Ketentuan Umum Perpajakan yang mengatur subtansi yang sama tidak dapat secara mutatis mutandis ditafsirkan bahwa sanksi pidana undang-undang a quo bersifat ultimum remedium namun harus ditafsirkan sebaliknya bahwa sanksi administrasi dapat ditegakan bersama-sama dengan sanksi pidana dengan mengingat perkembangan hukum pidana pajak yang memiliki karakter sebagai premium remedium $^{33}$. Artinya, sanksi administrasi yang telah ditegakan tidak serta merta menghapuskan tuntutan pidana melainkan apabila dalam pemeriksaan pajak ada persoalan administrasi dan juga ada indikasi tindak pidana maka keduaduanya bisa berjalan bersamaan dalam arti adminsitrasinya diselesaikan, pidananya juga diselesaikan karena berbeda kompetensinya sehingga permasalahan administrasi merupakan kompetensi Pengadilan Pajak dan tindak pidananya merupakan kompetensi Peradilan Umum.

Keenam, ketentuan Pasal 13A juncto Pasal 44B undang-undang a quo penghentian penyidikan terhadap tindak pidana di bidang perpajakan adalah

32 Muladi dan Barda Nawawi Arief, 1992, Bunga Rampai Hukum Pidana, Alumni, Bandung, hlm. 156.

33 Ch.J. Enschede, Op.Cit., hlm. 26. aturan yang bersifat fakultatif bukan bersifat imperatif. Hal ini ditandai dengan adanya kata 'dapat' dalam kalimat '..... dapat menghentikan penyidikan...”. Ketujuh, sebagaimana ketentuan Pasal 43A undang-undang a quo menunjukan bahwa tindak pidana pajak ada yang tunduk pada rezim undang-undang pemberantasan tindak pidana korupsi. Dengan demikian, sanksi pidana pajak tidak lagi bersifat ultimum remedium.

Perkembangan lebih lanjut Dewan

Perwakilan Rakyat dan Pemerintah mengeluarkan Undang-Undang Pengampunan Pajak dan sempat diuji materiil ke Mahkamah Konstitusi, namun ditolak seluruhnya. Ada beberapa catatan Penulis terkait undang-undang pengampunan pajak: Pertama, telah terjadi perubahan paradigma dalam hukum pidana moderen. Pada awalnya hukum pidana berorientasi pada keadilan retributif, yang mana hukum pidana lebih berorientasi pada pembalasan dengan mengedepankan hukum pidana sebagai lex talionis atau sarana balas dendam. Akan tetapi pada saat sekarang ini, paradigma hukum pidana moderen berorientasi pada keadilan korektif, rehabilitatif dan restoratif. ${ }^{34}$

Keadilan korektif berhubungandengan sanksi atas kesalahan pelaku, sedangkan keadilan rehabilitatif berkaitan dengan perbaikan terhadap pelaku agar tidak mengulangi perbuatan pidana, sementara keadilan restoratif bertalian dengan pemulihan atas kerugian yang ditimbulkan. In casu a quo, Undang-Undang Pengampunan Pajak telah beroreintasi pada paradigmahukum pidana moderen yang tidak lagi berorientasi pada penghukuman terhadap pelaku melainkan lebih pada pemulihan terhadap pendapatan negara dan dalam rangka memperbaiki pelaku untuk tikdak lagi mengulangi perbuatan yang sama di masa mendatang.

Kedua, ketika wajib pajak telah menyatakan semua harta kekayaan yang selama ini belum dilaporkan, kemudian atas pernyataan tersebut dikenakan pembayaran dengan prosentase tertentu, maka secara mutatis mutandis hal-hal yang berkaitan dengan pidana pajak dianggap selesai. Hal ini berkaitan dengan sifat dan karakter hukum pidana pajak sebagai ius singular sebagaimana yang telah dijelaskan di atas. Dalam konteks teori, hal yang demikian dikenal dengan istilah pointless of punishment. ${ }^{35}$ Menghukum yang tidak perlu

34 Eddy OS Hiariej, Op.cit., hlm. 52.

35 George P. Fletcher, 1998, Basic Concepts of Criminal Law, Oxford University Press, New York - Oxford., hlm. $813-814$. 
haruslah dihindari jika tujuan dari undang-undang sudah terpenuhi.

Ketiga, kerahasiaan informasi. Dalam Undang-Undang Pengampunan Pajak diatur bahwa informasi terkait data wajib pajak yang mengikuti pengampunan pajak dan dilarangnya pihak lain untuk mengakses atau memperoleh informasi tersebut pada hakikatnya tidaklah melanggar konstitusi yang bertalian dengan kebebasan memperoleh informasi. Di satu sisi, setiap warga negara memiliki hak kebebasan memperoleh informasi, namun di sisi lain, kebebasan memperoleh informasi bukanlah kebebasan mutlak yang tidak dapat dibatasi, melainkan kebebasan tersebut haruslah dibatasi jika berkaitan dengan privasi seseorang.

Keempat, perlu dipahami bahwa UndangUndang Pengampunan Pajak sama sekali tidak dimaksudkan untuk melegalkan praktik korupsi ataupun pencucian uang. Selain memiliki sifat dan karakter yang berbeda antara hukum pidana pajak dan hukum pidana korupsi serta hukum pidana pencucian uang, Undang-Undang Pengampunan Pajak hanya berkaitan dengan tindak pidana pajak. Hukum pidana pajak sebagai ius singular mengedepankan hukum pidana sebagai ultimum rimedium. Artinya, hukum pidana adalah sarana terakhir penegakan hukum setelah instumen penegakan hukum lainnya tidak lagi berfungsi dengan baik. Hal ini berbeda dengan hukum pidana dalam konteks korupsi dan pencucian uang yang mengedepankan hukum pidana sebagai primum rimedium. Artinya, hukum pidana sebagai sarana utama dalam memberantas kedua kejahatan tersebut.

Kelima, bertalian dengan pembuktian terbalik terhadap harta kekayaan wajib pajak. Berdasarkan undang-undang a quo, besarnya harta kekayaan yang belum dilaporkan diserahkan sepenuhnya kepada pernyataan wajib pajak. Hal ini tidak dapat serta merta ditafsirkan bahwa harta kekayaan yang belum dilaporkan merupakan hasil tindak pidana pencucian uang. Dalam tindak pidana pencucian uang kejahatan asal adalah causa proxima dari kejahatan pencucian uang. Tidak dilaporkan harta kekayaan yang sesungguhnya kepada fiscus atau pegawai pajak, tidaklah berarti harta kekayaan yang belum dilaporkan merupakan hasil yang ilegal. Selain itu, pembuktian terbalik dalam kontek Pasal 77 Undang-Undang Pencegahan dan Pemberantasan Tindak Pidana Pencucian Uang berkaitan dengan pembuktian harta kekayaan yang akan dirampas oleh negara manakala tidak dapat dibuktikan bahwa harta kekayaan tersebut tidak berasal dari suatu kejahatan.

Keenam, bertalian dengan Pasal 20 UndangUndang Pengampunan Pajak. Perlu ditegaskan bahwa pasal a quo tidak akan menghapuskan atau menghilangkan proses penegakam hukum pidana di luar tindak pidana pajak. Artinya, pasal a quo tidak menghapuskan penegakan hukum pidana dan tidak pula mengurangi kewenangan kekuasaan kehakiman untuk menegakkan hukum dan keadilan. Proses penegakan hukum pidana kepada pelaku pengampunan pajak tetap berlangsung sepanjang data dan infomrasi tidak berasal dari pelaksanaan pengampunan pajak. Artinya, tindak pidana lain di luar tindak pidana pajak tetap dapat diproses oleh penegakan hukum, jika dan hanya jika data yang diperoleh penegak hukum, pakah kepolisian, kejaksaan atau komisi pemberantasan korupsi memperoleh data tersebut bukan dari pelaksaaan pengampunan pajak. Dengan demikian ketentuan pasal a quo tidaklah bertentangan dengan prinsip kesederajatan di depan hukum.

\section{KESIMPULAN}

Berdasarkan berbagai uraian di atas, kesimpulan dari tulisan ini adalah: pertama, lex specialis systematis adalah derivat dari asas lex specialis derogat legi generali untuk menyelesaikan konflik antara dua atau lebih ketentuan dalam hukum pidana khsusus. Adapun syarat suatu hukum pidana khusus memenuhi kriteria sebagai lex specialis systematisitalic adalah selain adresat-nya bersifat khusus, baik ketentuan materiil maupun ketentuan formilnya menyimpang dari KUHP dan KUHAP; kedua, hukum pidana pajak memenuhi kriteria sebagai lex specialis systematis karena adresat-nya sangat khusus yaitu wajib pajak dan petugas pajak. Selain itu, baik ketentuan materiil maupun ketentuan formil dalam hukum pidana pajak menyimpang dari KUHP dan KUHAP sehingga saat dalam proses pengadilan ketentuan yang digunakan adalah ketentuan pidana perpajakan.

\section{SARAN}

Adapun saran yang dapat diusulkan kepada Dewan Perwakilan Rakyat dan Presiden sebagai pembentuk undang-undang adalah: perlu melakukan perubahan mendasar terhadap undangundang ketentuan umum pokok perpajakan dengan mengingat hukum pidana pajak adalah ius singular sebagai hukum adminstrasi yang diberi sanski pidana; serta substansi hukum pidana pajak 
sebagaimana yang diubah harus sesuai dengan sifat dan karakter hukum pidana kusus eksternal yang menempatkan sanksi pidana sebagai ultimum rimedium dengan pengutaaman sanksi administrasi sebagai subtitusi dari sanski pidana.

\section{UCAPAN TERIMA KASIH}

Penulis menghanturkan banyak terimakasih kepada Tuhan Yang Maha Kuasadan atas dukungan Isteri dan Anak-anak, serta keluarga, sehingga karya tulis ini dapat terselesaikan dengan baik. Ucapan terima kasih juga diucapkan kepada teman-teman yang tidak dapat disebutkan satu persatu, yang telah memberikan sumbang saran dan pemikiran, sehingga terselesaikannya karya tulis ilmiah ini.

\section{DAFTAR KEPUSTAKAAN}

Enschede, Ch.J., 2002, Beginselen Van Strafrecht, Kluwer, Deventer.

Fletcher, George P., 1998, Basic Concepts of Criminal Law, Oxford University Press, New York - Oxford., hlm. $813-814$.

Hiariej, Eddy O.S,2016, Prinsip-Prinsip Hukum Pidana, Cahaya Atama Pustaka, Yogyakarta.

Hiariej, Eddy O.S, 2018, Lex Specialis Dalam Hukum Pidana, KOMPAS, 12 Juni 2018.

International Monetary Fund, "Financial System Abuse, Financial Crime and Money Laundering", Background Paper, February 12, 2001, hlm. 3.

Kartanegara Satochid (tanpa tahun), Hukum Pidana, Balai Lektur Mahasiswa.

Lafave Wayne R., 2010, Principle Of Criminal Law, West A Thomson Reuters Business.

Larsson, Bengt, "What is 'economic' about 'economic crime'?", Chapter Buku, WhiteCollar Crime Research. Old Views and Future Potentials, The national council for crime prevention, Sweden, hlm. 123.

Muladi dan Arief, Barda Nawawi,1992, Bunga Rampai Hukum Pidana, Alumni, Bandung

Poernomo, Bambang, 1984, Pertumbuhan Hukum Penyimpangan Di Luar Kodifikasi Hukum Pidana, Bina Aksara, Jakarta

Remmelink, Jan, 2003, Hukum Pidana : Komentar Atas Pasal-Pasal Terpenting Dari Kitab Undang-Undang Hukum Pidana Belanda Dan Padanannya Dalam Kitab Undang-
Undang Hukum Pidana Indonesia, Penerbit PT Gramedia Pustaka Utama, Jakarta.

Yoserwan, 2020, Fungsi Sekunder Hukum Pidana Dalam Penanggulangan Tindak Pidana Perpajakan, Jurnal Penelitian Hukum DE JURE, Vol 20. No.2 (Juni 2020)

Undang-Undang No.6 Tahun 1983 tentang Ketentuan Umum dan Tata Cara Perpajakan Sebagaimana Telah Beberapa Kali Diubah Terakhir Dengan Undang-Undang Republik Indonesia Nomor 16 Tahun 2009

Undang-Undang 20 Tahun 2001 tentang Perunbahan Atas Undang-Undang Nomor 31 Tahun 1999 tentang Pemberantasan Tindak Pidana KorupsiPerbankan

Vos, H.B, 1950, Leerbook Van Nederlands Strafrecht, Derede Herziene Druk, H,D., Tjeenk Willink \& Zoon N.V. - Harlem 
HALAMAN KOSONG 